\title{
Miljøgifter og helserisiko
}

\author{
Helle K. Knutsen og Jan Alexander \\ Nasjonalt folkehelseinstitutt, divisjon for miljømedisin, avdeling for nceringsmiddeltoksikologi \\ Korrespondanse: Helle K. Knutsen, Nasjonalt folkehelseinstitutt, Postboks 4404 Nydalen, 0403 Oslo \\ Telefon: 22042473 Telefaks: 22042243 E-post: helle.knutsen@fhi.no
}

\begin{abstract}
SAMMENDRAG
Miljøgifter har lang halveringstid og akkumulerer i næringskjeden. Spesielt dioksiner, PCB og metylkvikksølv kan komme opp mot nivåer som gir grunn til bekymring. Med unntak av PCB finnes disse miljøgiftene naturlig, men vi har en betydelig menneskeskapt eksponering i tillegg. Dioksiner og dioksinliknende PCB vurderes samlet $\mathrm{i}$ toksikologiske risikovurderinger. De er fettløselige og kommer derfor opp i høyest nivåer i fettrike deler av dyr som er høyt oppe i næringskjeden. I norske matvarer er de høyeste nivåene å finne i måseegg, krabbe, fiskelever og fet fisk. Metylkvikksølv er ikke spesielt fettløselig og akkumulerer uavhengig av fettinnhold i for eksempel fiskekjøtt. I Norge er det mest metylkvikksølv å finne i ferskvannsfisk høyt opp i næringskjeden, som for eksempel gjedde, abbor og ørret. Også mer eksotiske saltvannslevende fiskeslag kan ha høyt kvikksølvinnhold. Det er vanskelig å fange opp høy eksponering for miljøgifter gjennom de ordinære kostholdsundersøkelsene, fordi det spises lite av matvarer med høyt miljøgiftinnhold i gjennomsnitt, mens enkeltpersoner kan konsumere mye. Gjennom den omfattende Fisk- og viltundersøkelsen vil miljøgifteksponeringen bli kartlagt bedre. Foreløpige resultater tyder på at for enkelte personer i Norge kan eksponering for metylkvikksølv, dioksiner og dioksinliknende PCB komme opp mot konsentrasjoner der faren for helseskader øker.
\end{abstract}

Knutsen HK, Alexander J. Environmental toxicants and health risk. Nor J Epidemiol 2004; 14 (2): 161-166.

\section{ENGLISH SUMMARY}

Some environmental toxicants have a long half-life and accumulate through the food chain. Especially dioxins, PCBs and methyl mercury can approach levels that may cause concerns. With the exception of PCB, these environmental toxicants are formed naturally. However, there are marked anthropogenic additional exposures. Dioxins and dioxin-like PCBs are evaluated jointly in toxicological risk assessments. Because they are lipid soluble, these contaminants approach high levels in fat-rich tissues of animals high up in the food chain. In Norwegian food items, the highest levels are found in seagull eggs, crabs, fish liver and in fatty fish species. Methyl mercury is not particularly lipid soluble and accumulates independent of fat content in e.g. fish muscle. In Norway the highest levels of methyl mercury are found in fish living high up in the food chain in freshwater, such as pike, perch and trout. Also, more exotic marine fish species may contain high levels of mercury. It is difficult to estimate high exposure to environmental toxicants via traditional food consumption surveys, because little of the foods containing high levels of environmental toxins are consumed in average, whereas some individuals may consume a lot. The extensive Norwegian Fish and Game study will provide better knowledge on environmental toxicant exposure. Preliminary results indicate that some individuals may approach exposure levels of methyl mercury, dioxins and dioxin-like PCBs where the risk of health injury increases.

Miljøgifter kjennetegnes ved at de er lite nedbrytbare og kan oppkonsentreres til skadelige konsentrasjoner i næringskjeden. Både tungmetaller som bly, kadmium og kvikksølv, og organiske stoffer som dioksiner, PCB (polyklorerte bifenyler), bromerte flammehemmere og DDT (diklor-difenyl-trikloretan) regnes blant miljøgiftene. Det er ofte oppslag i dags- og ukepresse om at maten vi spiser inneholder urovekkende høye nivåer av miljøgifter. Noen ganger beror oppslagene på misforståelser, andre ganger er det god grunn til å advare mot høyt konsum av spesielle typer matvarer. For de fleste miljøgifter er det god sikkerhetsmargin, det vil si stor avstand mellom det vi eksponeres for, og det som regnes som effektnivå. Imidlertid kan eksponering for dioksiner, PCB og metylkvikksølv i noen tilfeller komme opp mot nivåer som kan gi økt risiko for helseskadelige effekter.

\section{Dioksiner OG PCB}

Dioksiner brukes som en fellesbetegnelse på polyklorerte dibenzo-p-dioksiner (PCDD) og polyklorerte dibenzofuraner (PCDF), som det $\mathrm{i}$ alt finnes 210 forskjellige kongenere (strukturelt like forbindelser) av, med et varierende antall kloratomer. Deres toksisitet kan variere flere 10-potenser, noen er meget toksiske mens andre er svært lite toksiske. Det er vanligvis de forbindelsene som er substituert i 2,3,7,8-posisjon som anrikes i miljøet og gir de karakteristiske toksiske effektene av dioksiner (figur 1). Dioksiner har aldri vært 


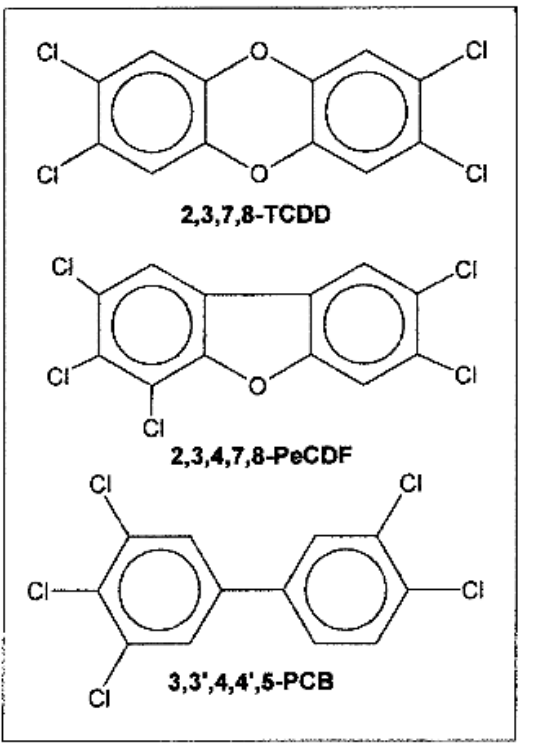

Figur 1. Struktur av dibenzo-p-dioksin, dibenzofuran og polyklorert bifenyl. Som eksempel er vist 2,3,7,8TCDD (tetraklordibenzo-p-dioksin), 2,3,4,7,8-PeCDF (pentaklordibenzofuran) og en pentaklorert PCB med alle kloratomer i non-orto posisjon.

produsert kommersielt, men dannes i spormengder i en del kjemiske prosesser, for eksempel ved metallproduksjon, og i forbrenningsprosesser der klor er til stede. Dioksiner kan også dannes i naturen ved for eksempel skogsbranner. Det har siden 80 -tallet vært betydelig nedgang i utslippene i Norge grunnet forbedrede renseprosesser og nedleggelse av metallproduksjon.

PCB hører også til gruppen av tungt nedbrytbare klororganiske forbindelser, og har siden 30-tallet vært produsert og anvendt $i$ et utall produkter, som for eksempel hydraulikkoljer, kondensatorer, transformatorer, maling, lim, fugemasse, etc. Bruk av PCB i nye produkter har vært forbudt siden 1982. PCB finnes i en rekke eldre bygninger og utlekking av PCB til miljøet er fortsatt et stort problem. Det finnes i alt 209 ulike PCB-forbindelser. De kan deles i to hovedgrupper, den ene bestående av 12 PCB med dioksinliknende effekter (non-orto og mono-orto substituerte, figur 1) og resten, som ikke har dioksinliknende effekter.

Både dioksiner og PCB er fettløselige, nedbrytes og utskilles langsomt av organismer og har derfor meget lang halveringstid. Det gjør at de oppkonsentreres i næringskjeden og følger hverandre i organismer som brukes til mat, som er menneskets vesentligste eksponeringskilde.

\section{Toksiske ekvivalensfaktorer (TEF) - verktoy for risikovurdering av blandinger av dioksiner og dioksinliknende PCB}

En antar at de fleste toksiske effekter av dioksiner og dioksinliknende PCB skyldes binding til og aktivering av dioksinreseptor (også kalt aryl hydrokarbonreseptor). Dette er en transkripsjonsfaktor som aktiverer en rekke cellulære prosesser. TCDD $(2,3,7,8$ - tetraklordibenzo-p-dioksin) er den mest potente aktivatoren av dioksinreseptor. Toksisitet av de 16 andre dioksinene og de 12 dioksinlignende PCB angis som toksiske ekvivalensfaktorer (TEF) i forhold til TCDD, som er tillagt verdien 1 [1]. Det antas at dioksiner og dioksinlignende PCB har samme virkningsmekanisme og at dosene er additive. Totalt innhold av dioksiner og dioksinlignende PCB målt $\mathrm{i}$ toksiske ekvivalenter (TE) $i$ en prøve beregnes ved å multiplisere innhold av hver enkelt kongener med den tilhørende TEF, og til slutt summere bidraget fra hver enkelt kongener.

\section{Effekter av lave doser dioksiner og dioksinliknende PCB}

I studier av rotter er det vist at ved eksponering for relativt lave doser dioksin under drektighet, er de kritiske effektene reproduksjonsforstyrrelser og nedsatt immunforsvar i avkommet. Ved noe høyere doser er dioksiner kreftfremkallende og gir svulster i flere organer i forsøksdyr, blant annet i lever.

Dioksiner er ikke gentoksiske, det vil si skader ikke DNA direkte, men virker sterkt tumorpromoverende (det vil si stimulerer vekst av celler som har fătt genskader). Dioksiner kan i tillegg til å aktivere dioksinreseptor-regulerte gener også påvirke hormonsystemer som virker via andre kjernereseptorer, som for eksempel de for østrogen, tyroksin og retinsyre. Dette er også mulige mekanismer bak effekter av relativt lave doser dioksiner.

\section{Effekter av lave doser ikke-dioksinliknende PCB}

PCB-blandinger gir økning av kreft, nedsatt immunforsvar og atferdsforstyrrelser i dyrestudier. Tolkning av resultatene vanskeliggjøres av at det ofte er benyttet kommersielle blandinger av PCB. Slike blandinger inneholder både dioksinlike og ikke-dioksinlike PCB. Dessuten inneholder maten vi spiser en annen PCBsammensetning (forskjellige kongenere og annet mengdeforhold) enn de kommersielle blandingene. Negativ assosiasjon mellom prenatal PCB-eksponering og kognitive funksjoner i spedbarn og barn er funnet $\mathrm{i}$ epidemiologiske studier, en studie viser også effekter av postnatal eksponering [2]. Konklusjoner fra disse studiene er imidlertid omdiskuterte [3].

\section{Tolerabelt ukentlig inntak (TWI) ble redusert i 2001}

Med bakgrunn i de toksikologiske virkningsmekanismene antar vi at det eksisterer doseterskel for de toksiske effektene av dioksiner. Tolerabelt ukentlig inntak (TWI) er den mengde av en forbindelse som vi med tilstrekkelig stor sikkerhetsmargin mener ligger under doseterskelen for effekt hos de aller fleste mennesker, og som derfor kan inntas hver uke hele livet uten at skade oppstår. Det er i denne sammenheng tatt hensyn til den lange halveringstiden og akkumulering av kroppsdosen. I de nordiske landene forholdt vi oss fram til 2001 til en TWI på 35 pg TE/kg kroppsvekt for dioksiner og dioksinliknende PCB. Dette inntaket var fastsatt av en nordisk ekspertgruppe i 1988 og 
1994 [4], til tross for at WHO regnet TWI som 70 pg TE/kg kroppsvekt fram til 1998 [5]. Ettersom ny kunnskap er frembragt foreslo EUs Scientific Committee on Food å redusere TWI til $14 \mathrm{pg}$ TE/kg kroppsvekt i 2001, og dette ble adoptert i alle europeiske land [6,7]. Joint FAO WHO Expert Committee on Food Additives (JECFA) fastsatte samme år et tolerabelt månedlig inntak på 70pg TE/kg kroppsvekt. Det ble valgt å angi tolerabelt inntak på månedsbasis på grunn av stoffenes lange halveringstid.

For de ikke-dioksinlike PCB er det foreløpig ikke fastsatt tolerabelt inntak, men dette arbeides det med i EFSA (Europeean Food Safety Authority).

\section{Eksponering $i$ Norge og ellers $i$ verden}

Dioksiner og dioksinliknende PCB har svært lang halveringstid i mennesket, i gjennomsnitt 7-8 år for TCDD. Det tar med en første ordens kinetikk derfor ca. 30 år med jevn eksponering før innholdet $\mathrm{i}$ kroppen slutter å øke, det vil si at det er oppnådd likevekt mellom det som tas opp og det som skilles ut. Man ser derfor tydelig aldersavhengige forskjeller $\mathrm{i}$ innhold av dioksiner og PCB i befolkningen.

For spedbarn er morsmelk en vesentlig kilde til eksponering for disse miljøgiftene. Spedbarns eksponering overskrider faktisk TWI flerfoldige ganger. Til tross for dette er det kjent at brystmelkernærte barn utvikler kognitive funksjoner bedre enn spedbarn som får morsmelkserstatning. Det er derfor god grunn til fortsatt å anbefale amming. Selv om spedbarn har en høy eksponering gjennom morsmelk, øker dette i liten grad det totale kroppsinnholdet etter noen år, fordi eksponeringstiden er forholdsvis kort og fordi barn vokser så fort at fortynningsfaktoren blir høy.

Innhold av dioksiner og PCB i matvarer og i befolkningen overvåkes. Resultater fra flernasjonale overvåkningsprogrammer tyder på at eksponering for dioksiner og dioksinlike PCB målt i sum toksiske ekvivalenter i Norge er på samme nivå som i resten av Vest-Europa. I Norge kommer imidlertid en høyere andel av dette fra PCB. Spesielt i Østersjøen er det en betydelig dioksinforurensning, slik at eksport av fisk fra Østersjøen ikke tillates. Overvåkning av innhold i morsmelk både i Norge og ellers i verden viser at eksponeringen er synkende. Morsmelksprøver fra tre forskjellige steder i Norge (Tromsø, Hamar og Skien/Porsgrunn) inneholder 159-278 ng PCB/g fett og 12-21 pg TE fra dioksiner og dioksinlignende PCB. Analysene viser 58\% nedgang i totalt PCB-nivå fra 1985/86 til 2000/01 og 61\% reduksjon av dioksiner [8].

\section{Eksponering $i$ Norge i forhold til TWI}

Ut fra matvareprøver som ble tatt ut tidlig på 90-tallet og inntaksdata via Statistisk sentralbyrås forbrukerundersøkelser 1992-94 ble det ukentlige inntaket av dioksiner og dioksinlike PCB i den norske befolkningen estimert til 950-1330 pg TE/person [9]. Marint fett er hovedkilden til klororganiske miljøgifter, men en del kommer også fra annet animalsk fett.

Reduksjonen av TWI fra 35 pg TE/kg/uke til 14 pg $\mathrm{TE} / \mathrm{kg} / \mathrm{uke}$ i 2001 gjorde at den beregnede gjennomsnittseksponeringen i Norge var litt høyere enn den nye TWI, som tilsvarer $980 \mathrm{pg}$ TE/uke for en person som veier $70 \mathrm{~kg}$. Imidlertid vet vi gjennom morsmelksprøver at eksponeringen er redusert. Mattilsynet er i gang med å koble nyere måledata fra matvarer til data om matinntak fra NORKOST (kvantitativ spørreundersøkelse om frekvens av inntak av forskjellige matvarer).

NORKOST-undersøkelsen er imidlertid ikke detaljert nok til at man får pålitelige opplysninger om inntak av matvarer som det spises lite av i gjennomsnitt, men som enkeltpersoner kan konsumere mye av. Matvarer med høyt miljøgiftinnhold er ofte å finne i denne kategorien. For blant annet å bedre kunne beregne eksponering for miljøgifter, har Folkehelseinstituttet og Mattilsynet (tidligere Statens næringsmiddeltilsyn) gjennomført Fisk- og viltundersøkelsen. Første del av Fisk- og viltundersøkelsen (del A) omfattet hele landet, der 6015 tilfeldig valgte personer mellom 18 og 79 år besvarte spørreskjema om frekvens av inntak av ulike matvarer [10]. I den andre delen (del B) av undersøkelsen besvarte 5502 tilfeldig valgte personer i 14 kystkommuner og 13 innlandskommuner med god tilgang til aktuelle matvarer det tilsendte spørreskjemaet [11]. Siste del (del C) av undersøkelsen omfatter høykonsumenter av aktuelle matvarer, og deltakerne er valgt fra del B av undersøkelsen. Dette er en dybdestudie av totalt 199 deltakere som har besvart detaljert spørreskjema om kosten og som har avgitt blod- og urinprøver for analyse av miljøgifter. Data fra undersøkelsene er under bearbeiding. Blant annet blir nivåer av dioksiner, PCB og andre organiske miljøgifter i mat som er målt i perioden 1999-2002 koblet mot inntaksdata fra Fisk- og viltundersøkelsen, slik at vi får et bedre anslag for samlet inntak og spredningen i inntaket for befolkningsgrupper med forskjellig konsummønster.

\section{Matvarer med hoyt innhold av dioksiner og PCB}

De høyeste nivåene av dioksiner og PCB finnes $i$ fettrike deler av sjølevende dyr som befinner seg høyt oppe i næringskjeden. Av de matvarer som konsumeres regelmessig i Norge er det spesielt torskelever og produkter av dette, måseegg og skallinnmat fra krabbe som peker seg ut som kilder (Tabell 1). Bare én porsjon av disse matvarene gir eksponering som er høyere enn det tolerable ukentlige inntaket, og da er ikke bidrag fra annen mat medregnet. Jevnlig inntak av disse matvarene vil øke eksponeringen for dioksiner og PCB i betydelig grad. Tabell 1 illustrerer også at ett måltid laks utgjør ca. $40 \%$ av maksimalt ukentlig inntak. Likeledes viser inntaksberegninger at fet fisk er en av de vesentligste bidragsyterne til dioksiner og PCB. Tran er et produkt av torskelever og inneholder $\mathrm{i}$ utgangspunktet høyt nivå av dioksiner og PCB, men produsentene har utviklet gode renseprosesser slik at 
inntak av en skje tran daglig av den kvalitet som leveres til markedet i svært liten grad påvirker eksponeringen. Figur 2 illustrerer en teoretisk beregning av hvordan forskjellige inntak av torskelever kan påvirke kroppsinnholdet av dioksiner og dioksinliknende PCB over tid. I del A av fisk- og viltundersøkelsen ble det funnet at ca. $30 \%$ av befolkningen spiser fiskelever [10]. I gjennomsnitt var inntaket blant konsumentene 1 $\mathrm{g} / \mathrm{dag}$, tilsvarende ca. 12 måltider $\mathrm{i}$ året med porsjonsstørrelse $30 \mathrm{~g}$. Et slikt inntak vil øke kroppskonsentrasjonen med ca. 35\% i løpet av 20 år. Fem prosent av konsumentene inntok mer enn 2,8 g torskelever/dag, og en slik inntaksrate vil doble kroppsinnholdet i løpet av 20 år.

Tabell 1. Miljøgiftinnhold i matvarer i forhold til TWI.

\begin{tabular}{lccc}
\hline Matvare & $\begin{array}{c}\text { Dioksiner }+ \\
\text { PCB } \\
(\mathrm{pg} \mathrm{TE} / \mathrm{g})\end{array}$ & $\begin{array}{c}\text { Innhold/ } \\
\text { porsjon* } \\
(\mathrm{pg} \mathrm{TE})\end{array}$ & $\begin{array}{c}\text { Overskridelse av TWI } \\
(980 \mathrm{pg} \mathrm{TE} \text { for person } \\
70 \mathrm{~kg})\end{array}$ \\
\hline Torskelever & 60 & 1800 & 1,8 \\
Krabbe & 20 & $>1300$ & $>1,3$ \\
Måseegg & 50 & 5000 & 5,1 \\
Laks & 2 & 400 & 0,4 \\
\hline
\end{tabular}

*Porsjonsstørrelser benyttet: Torskelever 30g, Krabbe $200 \mathrm{~g}$ (krabbesmør utgjør $1 / 3$ av spiselig del), et måseegg ca. $100 \mathrm{~g}$, fisk $200 \mathrm{~g}$.

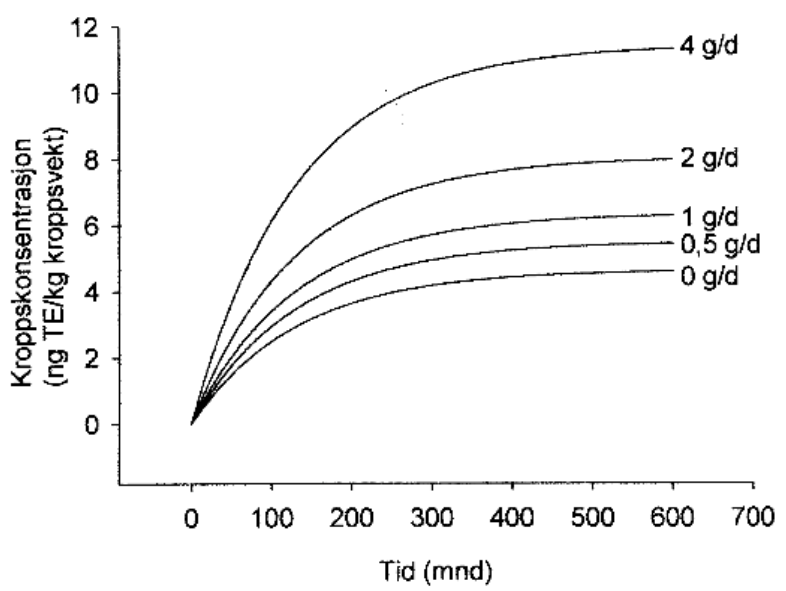

Figur 2. Teoretisk beregning av endringer i kroppskonsentrasjon av dioksiner og dioksinlike PCB målt i toksiske ekvivalenter (TE) ved ulik inntaksrate av torskelever. Kroppskonsentrasjonen er et resultat av forholdet [inntak - nedbrytning/utskilling]. Beregningen er foretatt med enkel førsteordenskinetikk, der degradering/utskilling ikke er avhengig av dose dioksiner og PCB. Beregningen forutsetter et innhold av dioksiner og dioksinliknende PCB på $60 \mathrm{pg} \mathrm{TE} / \mathrm{g}$ i torskelever, kroppsvekt på $70 \mathrm{~kg}$, halveringstid på 7,5 år, konstant inntak over svært lang tid samt at personen ikke tidligere har vært eksponert. Dette er en overforenkling av faktisk eksponering, men gir en indikasjon på hvordan ulike inntaksrater påvirker kroppskonsentrasjonen over lang tid. Null g/dag indikerer bakgrunnseksponeringen fra annen kost, beregnet i 1997 [9].

\section{Risikogrupper}

Personer som har høyt inntak av torskelever, krabbe og måseegg vil få en mye høyere kroppskonsentrasjon av dioksiner og PCB enn gjennomsnittet, og eksponeres for langt mer enn det som er tolerabelt ukentlig inntak. Imidlertid følger det alltid med en sikkerhetsmargin for tolerable inntak basert på toksikologiske dyreforsøk, der det tas hensyn til forskjeller mellom mennesker og dyr samt individuelle forskjeller $\mathrm{i}$ for eksempel metabolisme. Ved risikovurdering av dioksiner og PCB er det ca. 10 ganger forskjell mellom laveste dose som gir effekter i forsøksdyr og TWI. Eksponering utover TWI betyr ikke at man straks er oppe på nivåer som kan gi effekter, i første omgang er det sikkerhetsmarginen som reduseres.

Resultater fra dyreforsøk tyder på at pattedyr er mest utsatt for effekter av dioksiner og PCB på fosterstadiet. Det er grunn til å tro at ved lav eksponering er det den totale konsentrasjonen i den gravides kropp, som står i balanse med nivået i hennes blod, som har betydning for fosterets eksponering. På grunn av meget lang halveringstid er det inntaket helt fra barndommen av som bestemmer den totale kroppskonsentrasjonen av dioksiner og PCB i moren. Imidlertid vet man ikke i hvilken grad kortvarige høye doser under graviditet øker mors innhold i blodet, før miljøgiftene omfordeles til fettvev, og om dette eventuelt kan skade fosteret.

\section{Kostholdsråd}

For å sikre at kvinner i fruktbar alder og spesielt gravide ikke overskrider TWI, har Mattilsynet sendt ut kostholdsråd for disse gruppene. Rådet er at kvinner i fruktbar alder og spesielt gravide og ammende ikke bør spise måseegg eller torskelever og produkter som inneholder torskelever, og begrense inntaket av krabbeinnmat.

I en rekke havner og fjorder langs Norskekysten er sjøbunnen forurenset. I de områder der det er funnet forhøyet innhold av miljøgifter er det restriksjoner på omsetning av fisk og det er sendt ut lokale råd om å ikke spise selvfisket sjømat, og da som oftest torskelever. Disse kostholdsrådene er å finne på Mattilsynets hjemmesider [12].

\section{KVIKKSøLV}

Kvikksølv er et tungmetall som finnes naturlig, og som vi har en tilleggseksponering for på grunn av menneskelig aktivitet. Kvikksølv finnes som elementært kvikksølv i form av damp som kan skade hjernen dersom man eksponeres, mens uorganisk kvikksølvsalt kan skade nyrene. I maten foreligger det meste som organisk bundet kvikksølv, metylkvikksølv, som er nevrotoksisk. Uorganisk kvikksølv omdannes til metylkvikksølv i mikroorganismer i sedimenter. Metylkvikksølv krysser placentabarrieren og går over i morsmelk. Halveringstiden til metylkvikksølv er i 
mennesket rapportert å være 40-90 dager, og for kvikksølv oppnås det derfor likevekt mellom inntak og det som skilles ut mye raskere enn for dioksiner og $\mathrm{PCB}$, som har halveringstid på mange år.

\section{Effekter av metylkvikksolv}

Metylkvikksølv kan forårsake skade i mange organer, som nyrer, lever og forplantningsorganer. Imidlertid er hjernen det mest følsomme organet, og som rammes ved lavest eksponering. Også her er det slik at nervesystemet er mest følsomt når det er under utvikling, det vil si på fosterstadiet og i spedbarn. Fra omfattende studier på Færøyene der fostre har blitt eksponert via morens konsum av grindehvalkjøtt er det påvist doseavhengig reduksjon i blant annet finmotorikk, hukommelse og evne til å lære [13]. På den annen side viser studier fra Seychellene, der kvikksølveksponeringen kommer fra høy andel av fisk i kosten, ikke slik sammenheng [14]. Kvikksølveksponeringen i de to studiene er i samme størrelsesorden, og det er ikke kjent hva årsakene er til at det er målbare effekter i den ene studien og ikke i den andre.

De første merkbare effektene etter metylkvikksølveksponering i voksne er perifere parestesier (nummenhet, prikking og stikking) fulgt av redusert koordinering og artikulering. I de senere år er det også kommet rapporter om sammenheng mellom kvikksølveksponering og forhøyet blodtrykk, samt hjerte-karsykdommer både i barn og voksne [15].

\section{Tolerabelt inntak av kvikksolv}

Med bakgrunn i resultater fra studiene på Færøyene og Seychellene anbefalte JECFA (Joint FAO/WHO Expert Committee on Food Additives) i 2003 å redusere det tolerable inntaket av metylkvikksølv fra 3,3 til 1,6 $\square \mathrm{g} / \mathrm{kg}$ kroppsvekt/uke. Denne PTWI (provisory tolerable weekly intake) skal også beskytte fosteret. Det tolerable inntaket for kvikksølv totalt, er beholdt på 5 $\square \mathrm{g} / \mathrm{kg}$ kroppsvekt/uke [16].

\section{Eksponering}

Fisk og skalldyr er våre største kilde til metylkvikksølv, 80-100\% av kvikksølv i fisk foreligger som metylkvikksølv. Innhold av kvikksølv i fisk i Norge viser en svak oppadgående tendens. Det er en teori at dette skyldes langtransport av atmosfærisk kvikksølv nordover fra tett urbaniserte områder lenger sør. Innhold av kvikksølv i ferskvannsfisk viser en sør-nord gradient, med høyest nivå i sør. I tillegg kommer lokale utslipp som er et problem i noen fjordområder.

Foreløpige inntaksberegninger fra del $\mathrm{C}$ av fisk- og viltundersøkelsen tyder på at de aller fleste i Norge har en kvikksølveksponering som er vesentlig lavere enn JECFAs PTWI, både for totalt kvikksølv og metylkvikksølv. Enkeltindivider med spesielt høyt inntak av matvarer med høyt kvikksølvinnhold kan eksponeres for høyere nivåer av metylkvikksølv enn $1,6 \square \mathrm{g} / \mathrm{kg} / \mathrm{uke}$ (H.M. Meltzer og medarbeidere, upublisert).

\section{Matvarer med hoyt kvikksolvinnhold}

Stor rovfisk i ferskvann, som for eksempel gjedde, abbor og ørret, kan komme opp i nivåer på flere mg metylkvikksølv/kg, uten at vannet trenger å være berørt av lokale utslipp. Også saltvannslevende rovfisk, som for eksempel hai og tunfisk, kan ha høyt kvikksølvinnhold. Metylkvikksølv er ikke spesielt fettløselig, derfor er kvikksølvinnholdet i fisk ikke avhengig av om fisken er fet eller mager.

\section{Risikogrupper og kostholdsråd}

Fosteret og spedbarn er mest følsomme for kvikksølveksponering. For å sikre beskyttelse av disse, har Mattilsynet gitt råd om at gravide og ammende ikke bør spise følgende: gjedde, abbor over $25 \mathrm{~cm}$, ferskvannsørret over $1 \mathrm{~kg}$, røye over $1 \mathrm{~kg}$, eksotisk fisk (som hai, sverdfisk, skater, fersk tunfisk), hvalkjøtt. Andre deler av befolkningen bør ikke spise de ovennevnte fiskeslagene mer enn en gang $i$ måneden.

\section{ANDRE MILJØFORURENSNINGER}

I de senere årene har en rekke andre miljøforurensninger som benyttes i flammehemmere (f.eks. polybromerte difenyletere), plastmykgjørere (f.eks. ftalater), impregneringsmidler (f.eks. PFOS; perfluoralkylsulfonater), desinfeksjonsmidler (f.eks. triklosan), kosmetikk (f.eks. muskstoffer), gamle plantevernmidler (f.eks. toksafen), etc. fått mye oppmerksomhet. Dette er stoffer med høyst ulike egenskaper og toksisitet, men de har til felles at nivåene etter det vi kjenner til er lave sammenliknet med nivåer som kan gi helseskader. Det har vært spesielt mye fokus på bromerte flammehemmere i gruppen polybromerte difenyletere (PBDE) etter at det ble funnet oppsiktsvekkende høye nivåer i fisk og sedimenter i Mjøsa [17]. PBDE har struktur som likner på PCB, det finnes mange kongenere med ulik toksisitet, de er fettløselige og har lang halveringstid. Flere av de observerte effektene av PBDE i forsøksdyr minner også om de som observeres etter eksponering for ikke-dioksinlike PCB [18,19]. Både blodprøver og morsmelksanalyser viser at eksponeringen er stigende, men foreløpig er den betydelig lavere i Norge og i resten av Europa enn i USA, og ca. 10 ganger lavere enn totalt nivå av PCB [20]. Det er gjennomført få studier av kronisk eksponering for PBDE (blandinger og enkeltkongenere) i forsøksdyr, og det er ikke foretatt toksikologiske helserisikovurderinger av PBDE på internasjonalt nivå. Imidlertid viser norske beregninger at det er stor margin mellom observerte effektnivåer i forsøksdyr og det vi eksponeres for gjennom kosten, selv etter inntak av fisk fra Mjøsa.

\section{HELHETSSYN PÅ FISK}

Selv om fisk og skalldyr er vesentlige kilder for miljøgifter er det svært viktig å huske på alle de positive sidene ved fiskekonsum. Fisk er en viktig kilde til 
blant annet flerumettede fettsyrer (spesielt omega-3), vitaminer og mineraler. Det er lite ønskelig at fokus på miljøgifter skal føre til at det generelle fiskekonsumet $\mathrm{i}$ Norge reduseres. Spesielt i yngre aldersgrupper er det tendens til lavere fiskeinntak enn blant eldre [11], og dette er lite ønskelig helsemessig. Vitenskapskomitéen for mattrygghet er i gang med å foreta en helhetsvurdering av fisk og sjømat, for å komme med anbefalinger om inntak som tar både ernæringsmessige og toksikologiske hensyn.

\section{REFERANSER}

1. Van den Berg M, Birnbaum L, Bosveld AT, Brunstrom B, Cook P, Feeley M, et al. Toxic equivalency factors (TEFs) for PCBs, PCDDs, PCDFs for humans and wildlife. Environ Health Perspect 1998; 106: 775-792.

2. Schantz SL, Widholm JJ, Rice DC. Effects of PCB exposure on neuropsychological function in children. Environ Health Perspect 2003; 111: 357-576.

3. Kimbrough RD, Krouskas CA. Human exposure to polychlorinated biphenyls and health effects: a critical synopsis. Toxicol Rev 2003; 22: 217-233.

4. Ahlborg UG, Håkansson H, Wærn F, Hanberg A. Nordisk dioxinriskbedømning. 49. 1988. NORD.

5. Assessment of the health risk of dioxins: re-evaluation of the Tolerable Daily Intake (TDI). Executive summary. WHO Consultation May 25-29 1998, Geneva, Switzerland. http:/www.who.int/ipcs/publications/en/exesum-final.pdf.

6. Opinion of the SCF on the Risk Assessment of Dioxins and Dioxin-like PCBs in Food. 22-11-2000. http://europa.eu.int/comm/food/fs/sc/scf/out78 en.pdf.

7. Opinion of the Scientific Committee on Food on the Risk Assessment of Dioxins and Dioxin-like PCBs in Food. Update Based on New Scientific Information Available Since the Adoption of the SCF Opinion of 22nd November 2000. 30-5-2001. http://europa.eu.int/comm/food/fs/sc/scf/out90 en.pdf.

8. Becher G, Haug LS, Nicolaysen T, Polder A, Skaare JU. Temporal and spatial trends of PCDDs/PCDFs and PCBs in Norwegian breast milk - results from three rounds of WHO co-ordinated studies. Organohalogen Compounds 2002; 56: 325-328.

9. Becher G, Skaare JU, Eriksen GS, Lund-Larsen K. Dioksiner og dioksinlignende PCB i næringsmidler i Norge. 1997, SNT-rapport 9.

10. Meltzer HM, Bergsten C, Stigum H. Fisk- og Viltundersøkelsen. Konsum av matvarer som kan ha betydning for inntaket av kvikksølv, kadmium og PCB/dioksin i norsk kosthold. 2002, SNT Rapport 6.

11. Bergsten C. Fish- and Game Study. The consumption of foods that may be important when assessing the dietary intake of mercury, cadmium and $\mathrm{PCB} /$ dioxins, with a focus on population groups living on the coast and in the inland of Norway. 2004, The Norwegian Food Safety Authority. http://www.mattilsynet.no/ multimedia/archive/00006/Fisk og_vilt_Fish_and 6317a.pdf.

12. Råd til gravide. 2004, Mattilsynet. http://snt.mattilsynet.no/nytt/kosthold/gravide/.

13. Steuerwald U, Weihe P, Jorgensen PJ, Bjerve K, Brock J, Heinzow B, Budtz-Jorgensen E, Grandjean P. Maternal seafood diet, methylmercury exposure, and neonatal neurologic function. J Pediatr 2000; 136: 599-605.

14. Myers GJ, Davidson PW, Cox C, Shamlaye CF, Palumbo D, Cernichiari E, et al. Prenatal methylmercury exposure from ocean fish consumption in the Seychelles child development study. Lancet 2003; 361: 16861692.

15. Chan HM, Egeland GM. Fish consumption, mercury exposure, and heart diseases. Nutr Rev 2004; 62: 68-72.

16. Joint FAO/WHO Expert Committee on Food Additives. Sixty-first meeting. Rome, 10-19 June 2003. Summary and conclusions. JECFA . 2003. ftp://ftp.fao.org/es/esn/jecfa/jecfa61sc.pdf.

17. Fjeld E, Schlabach M, Berge JA, Eggen T, Snilsberg P, Källberg G, et al. Kartlegging av utvalgte nye organiske miljøgifter - bromerte flammehemmere, klorerte parafiner, bisfenol A og triclosan. 2004. SFT. http://www.sft.no/publikasjoner/kjemikalier/2006/ta2006.pdf.

18. Darnerud PO, Eriksen GS, Johannesson T, Larsen PB, Viluksela M. Polybrominated diphenyl ethers: occurrence, dietary exposure, and toxicology. Environ Health Perspect 2001; 109 Suppl 1: 49-68.

19. McDonald TA. A perspective on the potential health risks of PBDEs. Chemosphere 2002; 46: 745-755.

20. Thomsen C, Frøshaug M, Leknes H, Becher G. Brominated flame retardants in breast milk from Norway. Organohalogen Compounds 2003; 64: 33-36. 